\title{
Museu da Escola Paranaense
}

\section{Maria Helena Pupo Silveira}

O crescimento significativo de espaços museais destinados à educação é um fenômeno mundial. Algumas denominações como: Museus Pedagógicos, Museu de História da Educação ou Museu da Educação foram estabelecidos a partir da década de 1980 para preservar os acervos educativos de algumas cidades da Europa.

Inúmeras motivações se deram a partir de projetos de museus de escolas, principalmente a necessidade de documentar e interpretar a escola no passado. Postura, por vezes, nostálgica, na tentativa de salvar e resgatar a memória daquilo que pode desaparecer e, de outro lado, também propõe uma interpretação de uma corrente pedagógica na tentativa de entender o presente e projetar o futuro.

Outras motivações surgiram no cenário da decadência de um modelo de escola, nascida no século XIX, que passa a ser questionado a partir de 1960. Com o advento da tecnologização da sociedade, mais fortemente a partir de 1990, uma série de objetos, livros, cadernos, planejamentos e materiais pedagógicos se tornaram obsoletos, não didáticos e acabaram por desaparecer das escolas.

Estas práticas, não registradas oficialmente, configuram-se numa cultura própria da escola. Mesmo algumas delas "superadas", fizeram parte da formação de várias gerações. Por isso devem ser lembradas e mais, investigadas. A necessidade de preservação de "velhas práticas pedagógicas", "mobiliários", "edifícios" não se resume pelas suas belezas ou monumentalidade, mas mostrar às novas gerações as rupturas e continuidades do atual modelo escolar.

O fim de uma fase histórica e início de outra, ou seja, a passagem do século XX para o XXI possibilitou novos conceitos de memória. Um desses foi o conceito introduzido pela noção de "cultura escolar", no campo da história cultural "

Esse olhar da escola permite entendê-la como entidade produtora de uma cultura específica, original. Possível, portanto, de realização de estudos variados, particularmente da recuperação de inúmeros objetos esquecidos pela História da Educação tradicional, mas fundamentais para a reconstituição da sua história.

Muitos museus da escola foram criados a partir dessas iniciativas de pesquisa, de uma nova História da Educação que revaloriza o patrimônio escolar.

${ }^{1}$ Ver FARIA FILHO, Luciano et al. A cultura escolar como categoria de análise e como campo de investigação na História da Educação brasileira. Caderno de Educação e Pesquisa, São Paulo, v. 3 n. 1, p. 133-159, jan./abr. 2004. 
A proposta de criação do Museu da Escola Paranaense se insere nesse tipo de iniciativa, na medida em que propõe resgatar, recuperar e proteger o patrimônio das escolas da Rede Pública Estadual, colocando-os à disposição da sociedade paranaense para estudos, reconstituição de sua história e memória educacional, ou simplesmente para resgatar lembranças do modo como se realizavam as práticas educativas escolares no Paraná.

É com muito prazer que o Núcleo de Pesquisa do Patrimônio Histórico Escolar, junto à Secretaria de Estado da Educação, apresenta aos pesquisadores em geral, aos alunos e professores um espaço que se propõe a ser uma instituição científico-educacional, que surge da necessidade social de recuperação e preservação da história da Escola Pública do Estado do Paraná.

É preciso considerar que o conceito de museu, no entanto, vem passando por modificações e assumindo nova dimensão, não se limitando apenas ao papel de simples mostra e depósito de objetos, mas contribuindo para ações de educação patrimonial.

Por isso, defende o Conselho Federal de Museologia-COFEM - que: "os museus, mais do que casas onde dormem esquecidos alguns objetos são campos de memória e espaços de relações e práticas sociais".

Esperamos a contribuição e a participação de toda a sociedade paranaense nesse empreendimento que não é de um governo, mas do Estado do Paraná.

Maria Helena Pupo Silveira

Doutora em Educação

Coordenação do Núcleo de Pesquisa do Patrimônio Histórico Escolar/SEED

Museu da Escola Paranaense

Decreto $\mathrm{n}^{\circ} 8242$ de 16 de maio de 2013 


\section{DECRETO No 8.242}

(Publicado no Diário Oficial do Paraná no dia 16 de maio de 2013, Caderno Poder Executivo Estadual, Edição no 8959, p. 4)

Cria o MUSEU DA ESCOLA PARANAENSE no âmbito da Secretaria de Estado da Educação.

O GOVERNADOR DO ESTADO DO PARANÁ, no uso das atribuições que lhe confere o art. 87, incisos V e VI da Constituição Estadual e tendo vista o disposto na Lei $\mathrm{n}^{\mathrm{o}} 8.485$, de 3 de junho de 1987 e ainda,

considerando a importância do patrimônio cultural, material e imaterial existente nas escolas da Rede Pública Estadual da Educação, representado pelas edificações, acervos documentais, mobiliários, equipamentos, instrumentos e memórias escolares que, por sua natureza, compõem a memória educacional e a história educacional paranaense;

considerando que a Secretaria de Estado da Educação necessita de espaços de guarda adequados para os acervos documentais, mobiliários e equipamentos pedagógicos escolares de valor histórico e cultural, bem como de recursos técnicos e pessoal especializado para orientar e cuidar do patrimônio histórico escolar; e considerando que a Constituição Federal, nos artigos 215 e 216, estabelece que o Estado deve garantir a todos o pleno exercício dos direitos culturais e acesso às fontes da cultura nacional, bem como apoiar e incentivar a valorização e a difusão das manifestações culturais, em colaboração com a comunidade e promover e proteger o patrimônio cultural brasileiro por meio de inventários, registros, vigilância, tombamento, acautelamento, preservação e ações de Educação Patrimonial,

\section{DECRETA:}

Art. $1^{\circ}$ Fica criado, no âmbito da Secretaria de Estado da Educação do Paraná, vinculado ao Gabinete do Secretário, o MUSEU DA ESCOLA PARANAENSE, destinado a recolher, abrigar, conservar, preservar e expor o patrimônio histórico e cultural das Escolas do Estado do Paraná, além de fomentar e divulgar a história da educação e as memórias das práticas educativas da comunidade escolar paranaense.

$\S 1^{\circ}$. O MUSEU DA ESCOLA PARANAENSE será composto por uma sede central em Curitiba e articulado a uma rede de Centros de Memória Escolares e Regionais, como forma de garantir sua abrangência estadual.

$\S 2^{\circ}$. As Escolas Públicas Estaduais estarão vinculadas ao MUSEU DA ESCOLA PARANAENSE por meio de CENTROS DE MEMÓRIA, os quais serão implantados segundo critérios estabelecidos pelo Plano Diretor do Museu. 
Art. $2^{\circ} \mathrm{O}$ MUSEU DA ESCOLA PARANAENSE terá como objetivo resgatar e preservar a história da escola paranaense e estimular estudos e pesquisas no campo da Educação Escolar, constituindo-se em espaço vivo, dinâmico e integrado à comunidade.

Art. $3^{\circ} \mathrm{O}$ MUSEU DA ESCOLA PARANAENSE atenderá à preservação do patrimônio material e imaterial das escolas da Rede Estadual, a partir de quatro eixos de ação: acervos mobiliários, pedagógicos e documentação escolar; acervo arquitetônico escolar; acervo imaterial da cultura escolar; e formação e educação patrimonial.

Art. $4^{\circ}$ Compete ao MUSEU DA ESCOLA PARANAENSE planejar, aprovar e acompanhar as ações de educação patrimonial nas escolas públicas do Estado e incentivar a constituição dos Centros de Memória nas Escolas Estaduais.

Art. $5^{\circ} \mathrm{O}$ MUSEU DA ESCOLA PARANAENSE desenvolverá programa permanente de capacitação dos servidores das escolas e Centros de Memórias constituídos, envolvendo a educação patrimonial e disseminando diversas técnicas de tratamento e gestão de acervos museais.

Art. $6^{\circ}$ A Secretaria de Estado da Educação do Paraná providenciará instalações adequadas para o funcionamento do MUSEU DA ESCOLA PARANAENSE.

Art. $7^{\circ}$ Os acervos do MUSEU DA ESCOLA PARANAENSE são aqueles pertencentes às Escolas Públicas Estaduais do Paraná e aos setores da Secretaria de Estado da Educação que, a critério do Conselho Consultivo do MUSEU, sejam considerados de valor museológico.

Art. $8^{\circ} \mathrm{O}$ MUSEU DA ESCOLA PARANAENSE terá regimento e plano museológico específicos, de acordo com as Leis Federal e Estadual de Museus.

Art. $9^{\circ}$ Fica ao MUSEU DA ESCOLA PARANAENSE assegurada a condição de unidade de execução orçamentária própria, proveniente de recursos do Tesouro do Estado do Paraná, na Secretaria de Estado da Educação, a partir do próximo exercício.

Art. 10 Este Decreto entra em vigor na data de sua publicação.

Curitiba, em 16 de maio de 2013, $192^{\circ}$ da Independência e $125^{\circ}$ da República.

$$
\text { FLÁVIO ARNS }
$$

Governador do Estado, em exercício

CEZAR SILVESTRI

Secretário de Estado de Governo

JORGE EDUARDO WEKERLIN

Secretário de Estado da Educação, em exercício 